\title{
Literature Review of Good Teachers: The Attributes and Gaps of Indonesian Teachers as a Profession
}

\author{
Een Yayah Haenilah ${ }^{1 *}$ \\ Hasan Hariri ${ }^{1}$ \\ Ridwan $^{2}$ \\ Onojah Amos Ochayi ${ }^{3}$ \\ Albet Maydiantoro' \\ M. Arifki Zainaro ${ }^{4}$ \\ John Rainer T. Bolado5 \\ Tubagus Ali Rachman Puja Kesuma ${ }^{6}$ \\ Rias Tusianah $^{7}$ \\ Usastiawaty C.A.S. Isnainy ${ }^{4}$
}

${ }^{1}$ Faculty of Teacher Training and Education Universitas Lampung, Jl. Prof.Dr. Ir. Sumantri Brojonegoro No.1, Gedong Meneng, Rajabasa,

Bandar Lampung City, Lampung 35145, Indonesia

${ }^{2}$ SMP Negeri 3 Way Pengubuan, Trimulyo Mataram, Seputih Mataram, Central Lampung Regency, Lampung 34164, Indonesia

${ }^{3}$ Faculty of Education University of Ilorin,

P.M.B 1515. City of Ilorin, Kwara State, Nigeria

${ }^{4}$ Universitas Malahayati, Jl. Pramuka No.27, Bandar Lampung City,

Lampung Lampung 35152, Indonesia

${ }^{5}$ San Agustin Integrated School, Philippine Department of Education,

San Agustin Road, San Fernando City, Philippines

${ }^{6}$ Institut Agama Islam Negeri (IAIN) Metro, Jl. Ki Hajar Dewantara No.15A,

Metro City, Lampung 34112, Indonesia

${ }^{7}$ SMP Negeri 1 Seputih Agung, Simpang Agung, Seputih Agung,

Central Lampung Regency, Lampung 34162, Indonesia

*Corresponding Author

DOI: https://doi.org/10.36941/ajis-2022-0044

\section{Abstract}

Attributes of good teachers are under-research, particularly in comparison between the Indonesian context and worldwide. This review aims to find out the compatibility and the gap of the good teacher attributes between the teachers of Indonesia and worldwide. The main inclusion criteria were the articles published in English between 2007 and 2020. The authors collected 206 articles; however, 174 articles were excluded. The authors reviewed 32 that met the inclusion criteria. The findings indicate that the good teacher attributes of Indonesia are compatible with the global ones, and the gap is mindfulness attribute. It is the consciousness of a professional choice to get feeling peace in life. Implications of these findings are theoretical and practical.

Keywords: good teacher's attributes, literature review, teachers of Indonesia 


\section{Introduction}

The profession is the main source of one's identity and its activities make that benefit personally. The benefits can be in the form of recognition of the social community, connection to the relationships with other people, position in society, and feelings of usefulness (Kadioglu Ates \& Kadioglu, 2018). These benefits result in satisfying lives. The satisfaction in leading a life triggers psychological wellbeing, likewise, with the teacher as a profession if the person chooses it with mindful-awareness. Mindful awareness means that the person knows and is ready with all the risks adhere.

Likewise, with teachers as a profession, the work of teachers is as old as the history of mankind. They carry out various tasks and functions although they depend on the social and cultural structure of each place and era. Educators hold the services and obligations needed in shifting common and cultural values to the next generation, realizing social unity, and building a harmonic community (Dogan, Yildirim, Cermik, \& Ates, 2020; Jabborov, 2020). The noble teacher's job is to educate and teach. Teaching is a process that results from the emergence of human learning abilities that occur throughout life. The teacher's job apart from teaching is to educate. Educating is the accumulation and the peak of human knowledge in the search for life's tasks (Aydin et al., 2019). At present, the task of teachers in teaching and educating is increasingly complex in line with the pace of development of world modernity, in particular being an effective teacher.

There have been many attempts to define teaching effectiveness and effective teachers. In general, effective teachers need not only the knowledge but also the desired skills to achieve teaching goals. Teachers must also be able to use this knowledge and skills properly if teaching goals are to be achieved. While focusing on the features of a supreme teacher, definitions of terms such as effective teacher should be identified.

The challenge to become an effective teacher is to balance between two poles: the world is changing rapidly today in one pole, while the aim of education is to nurture individuals to have sufficiently qualified competencies to stay up with the developments in the modern world while maintaining human values in another pole (Celik, 2017). This can all happen if there are teachers of the desired standard quality. Teachers who have compliance with quality standards are the teacher who will be able to convey and balance those poles, and teach to students well (Kadioglu Ates \& Kadioglu, 2018). It is identified that a good teacher has several terms, such as effective teacher, and/or a professional teacher. In order to investigate the gap between the attributes of good teacher prerequisites in Indonesia and worldwide, we identified the characteristics. This is because the term of professional teacher in Indonesia has still complained by the Indonesia stakeholders. The term of professional teacher introduced since the launch of the teacher certification in 2007. This is where this research is important.

\section{The Statement of the Problem and the Purpose}

There was an investigation showing that teachers reported a higher degree of work stress contrasted to nonhuman service professions (B. M. Johnson et al., 2005; D. W. Johnson \& Johnson, 2017). Being a teacher with a lot of demands makes this profession can be stressful. For this reason, teachers need emotional involvement which is necessary for continuous involvement, attention, psychological flexibility, psychological regulation, self-confidence, and resilience (Cook-Sather \& Baker-Doyle, 2017; Hargreaves, 1998; Roeser, Skinner, Beers, \& Jennings, 2012).In this setting, a literature review of the characteristics of a good teacher was explored from many studies conducted by researchers around the globe. This research is important, at least, there has not been much research on the comparison of good teachers in the world and specifically compared with the Indonesian version of good teachers. For this purpose, the research questions of this literature review are (a) what are the attributes of a good teacher? (b) Do the characteristics of a good teacher of Indonesia match those found in various world studies? (c) If any, what are the gaps? 


\section{Method}

To limit this research to recent developments in investigating the traits of good teachers, only papers published between 2007 and 2020 were reviewed. A total of 206 documents were gained from the Google scholar's search mechanism, which was obtained using the keywords of a good teacher, effective teacher, and professional teacher. A total of 174 papers were released because they did not meet the criteria being sought. As many of 32 that relevant papers were published between 2007 and 2020.

A total of 32 the purpose articles were identified came from The International Journal of Training Research, Journal of Medical Education Development, Phys. Educ. 55 IOP Publishing Ltd, IJASOS- International E-Journal of Advances in Social Sciences, Springer Nature Singapore Pte Ltd, European Journal of Education Studies, Encounters in Theory and History of Education, Creativity studies, Malaysian Online Journal of Educational Sciences, Educational Researcher, Childhood Education, South African Journal of Education, Journal of Further and Higher Education, Educational Studies, Asia-Pacific Journal of Teacher Education, Journal of Criminal Justice Education, Sport, Education and Society, Teacher Development, Springer Science + Business Media, LLC, Universal Journal of Educational Research, Australian Journal of Teacher Education, European Journal of Educational Research, British Journal of Educational Psychology, Journal of Education and Human Development, Lärande och samhälle, ictactjournals.in, International Journal of Foreign Language Teaching \& Research, Educational Psychology Review, Research on Humanities and Social Sciences, researchgate.net, The Asian ESP Journal, Teaching, and Teacher Education. The article comes from research in countries including Australia, Iran, Sweden, Indonesia, Slovakia, Lithuania, Turkey, Ghana, Canada, South African, Hong Kong, Spain, USA, Norway, Vietnam, Hungary, Germany, Greece, India, Iran, India, and Iraqi Kurdistan.

The 32 documents that fulfill the selection standard were taken in the study. The criteria are papers must be written in English and without looking at levels and all types of research in a variety of background subjects. To get a better comprehension of this subject, relevant discursive papers (review papers) are also included. Papers are issued if they do not indicate, examine, and declare the attributes of a good teacher.

\section{Results}

The data that we use in this literature review are articles that we get from a Google Sholar search and sourced from journals as stated in the methods section. We present the analysed articles listed in Table 1.

Table 1: Articles Examined

\begin{tabular}{|l|l|l|l|}
\hline No. & Writer(s) & Attributes identified & Country \\
\hline 1. & Smith and Yasukawa (2017) & $\begin{array}{l}\text { negotiate } \\
\text { speech } \\
\text { deeds } \\
\text { has different relationships } \\
\text { industry practitioners } \\
\text { business acumen in market-based vet systems } \\
\text { interpret and predict power markets to gain insight into their effectiveness as border } \\
\text { crossers }\end{array}$ & Australia \\
\hline 2. & $\begin{array}{l}\text { culture } \\
\text { training } \\
\text { Gesearch } \\
\text { executive } \\
\text { confidence } \\
\text { spirit } \\
\text { behavior } \\
\text { agency } \\
\text { cognitive } \\
\text { emotional }\end{array}$ & Iran \\
\hline
\end{tabular}




\begin{tabular}{|c|c|c|c|}
\hline No. & Writer(s) & Attributes identified & Country \\
\hline 3. & De Winter and Airey (2019) & $\begin{array}{l}\text { knowledge of physics subjects } \\
\text { respect for science } \\
\text { covers science practice and proofs } \\
\text { break down science/pitch content accordingly } \\
\text { good at math the math requests of learners } \\
\text { apt to perform great science pedagogical options } \\
\text { utilize patterns and descriptions of science concepts }\end{array}$ & Sweden \\
\hline 4 . & (Akhtar, 2017) & $\begin{array}{l}\text { accepting yourself } \\
\text { positive relationships with others } \\
\text { independence } \\
\text { environmental control } \\
\text { life goals } \\
\text { personal growth } \\
\end{array}$ & Indonesia \\
\hline 5. & Fleer (2018) & $\begin{array}{l}\text { emotional imagination to explore new methods of tutoring science ideas to youngsters } \\
\text { in initial adolescence environments }\end{array}$ & Australia \\
\hline 6. & Tarajová and Metruk (2020) & $\begin{array}{l}\text { Uses many activities in set activity and teamwork where students } \\
\text { can interact and be active } \\
\text { participate in the learning process } \\
\text { have sufficiently deep expertise } \\
\text { subject matter } \\
\text { deep interest } \\
\text { have passion } \\
\text { have the ability to use a variety of ways, method, strategy } \\
\text { flexible } \\
\text { describe the curriculum in a simple and natural way that students believe } \\
\text { personality teacher } \\
\text { knowledge of English } \\
\text { mastery } \\
\text { pedagogical skills } \\
\text { knowledge of planning methodologies }\end{array}$ & Slovakia \\
\hline 7 . & O'Donoghue (2016) & $\begin{array}{l}\text { master the subject matter very well in their teaching area } \\
\text { teachers must know how to teach } \\
\text { teachers, together with education studies students and policy makers } \\
\text { must be involved in reflection not only on classroom work } \\
\text { broader education }\end{array}$ & Australia \\
\hline 8. & $\begin{array}{l}\text { Navickiené, Sedereviciuté-Paciauskiené, } \\
\text { Valantinaité, and Zilinskaité-Vytiené } \\
(2019)\end{array}$ & $\begin{array}{l}\text { Individualrevelation } \\
\text { communicative } \\
\text { lifetime education } \\
\text { methodology } \\
\text { preparation } \\
\text { organization } \\
\text { effectiveness } \\
\text { appraisal }\end{array}$ & Lithuania \\
\hline 9 . & Cansoy and Parlar (2018) & $\begin{array}{l}\text { professional, and } \\
\text { collective learning } \\
\text { collective cooperation }\end{array}$ & Turkey \\
\hline 10. & Akyeampong (2017) & $\begin{array}{l}\text { learner-centered pedagogical principles that can be implemented in many kinds of } \\
\text { classes } \\
\text { Mathematical settings and issues } \\
\text { effective practicum }\end{array}$ & Ghana \\
\hline 11. & Grant (2017) & $\begin{array}{l}\text { be a careful teacher } \\
\text { social competence } \\
\text { high emotional level and quality } \\
\text { responsive } \\
\text { dialectical } \\
\text { do not judge } \\
\text { self-regulating }\end{array}$ & Canada \\
\hline 12. & (Rusznyak, 2018) & $\begin{array}{l}\text { their personal morals } \\
\text { shared ethical obligations } \\
\text { social dimension } \\
\text { morals and } \\
\text { affective } \\
\text { a reasonable judgment } \\
\end{array}$ & $\begin{array}{l}\text { South } \\
\text { African }\end{array}$ \\
\hline 13. & Morrison and Evans (2018) & $\begin{array}{l}\text { support student learning } \\
\text { encourages critical thinking } \\
\text { clear explanations supported by relevant and } \\
\text { practical examples }\end{array}$ & Hong Kong \\
\hline 14. & Esteban Bara and Mellén Vinagre (2019) & authentic personality & Spain \\
\hline 15. & $\begin{array}{l}\text { Maddamsetti, Flennaugh, and Rosaen } \\
(2018)\end{array}$ & $\begin{array}{l}\text { an intellectual with deep knowledge } \\
\text { become a moral role model based on Confucianism }\end{array}$ & The USA \\
\hline 16. & Benekos (2016) & $\begin{array}{l}\text { personality } \\
\text { knowledge } \\
\text { engaging pedagogical skills demonstrated with passion and enthusiasm }\end{array}$ & The USA \\
\hline 17. & Lyngstad, Bjerke, and Lagestad (2019) & shows the importance of the teacher giving cues that students are understood & Norway \\
\hline
\end{tabular}




\begin{tabular}{|c|c|c|c|}
\hline No. & Writer(s) & Attributes identified & Country \\
\hline & & $\begin{array}{l}\text { exceeding the aspects of abilities and understanding in the classroom highlight a } \\
\text { variety of emotions students may have } \\
\text { feedback that promotes learning } \\
\text { respect } \\
\text { trust }\end{array}$ & \\
\hline 18. & Nguyen, Haworth, and Hansen (2019) & $\begin{array}{l}\text { have firm credos concerning the advantages of dynamic training } \\
\text { redefining their role in the classroom, } \\
\text { support learners in creating innovative information critically and meaningfully by the } \\
\text { integration of extra active education approach developments in their practices }\end{array}$ & Vietnam \\
\hline 19. & $\begin{array}{l}\text { Braun, Roeser, Mashburn, and Skinner } \\
(2019)\end{array}$ & $\begin{array}{l}\text { lower job stress } \\
\text { work fatigue } \\
\text { depressive symptoms } \\
\text { worry } \\
\text { emotionally supportive teacher interactions with students in the classroom are the } \\
\text { most stressful }\end{array}$ & The USA \\
\hline 20. & Ida (2017) & $\begin{array}{l}\text { educators who make many attempts to help learners with the gaining. } \\
\text { individual care } \\
\text { handle learner difficulties } \\
\text { right approach and } \\
\text { show honor for one another }\end{array}$ & Hungary \\
\hline 21. & Teng (2017) & emotional changes & Hong Kong \\
\hline 22. & Kadioglu Ates and Kadioglu (2018) & $\begin{array}{l}\text { individual accountability } \\
\text { creativity } \\
\text { the ability to solve problems } \\
\text { analytical thought } \\
\text { teamwork } \\
\text { the capacity to start changes } \\
\text { recognition } \\
\text { love } \\
\text { concession } \\
\text { great common relations } \\
\text { moral values } \\
\text { expert understanding relating to the material in a particular field of instructional } \\
\text { competence linked to the pedagogical work }\end{array}$ & Turkey \\
\hline 23. & Baier et al. (2019) & $\begin{array}{l}\text { extraversion } \\
\text { enthusiasm for teaching } \\
\text { pedagogical knowledge } \\
\text { psychological }\end{array}$ & Germany \\
\hline 24. & Platsidou and Diamantopoulou (2020) & \begin{tabular}{|l|} 
trust \\
self-control \\
awareness \\
communication skills \\
cooperation \\
organizational knowledge \\
drive \\
achievement adjustment \\
build relationships \\
transformation spur \\
\end{tabular} & Greece \\
\hline 25. & Jamei (2016) & $\begin{array}{l}\text { be definite } \\
\text { have a certain personality } \\
\text { be a motivator } \\
\text { be supporters } \\
\text { be good command of English } \\
\text { listen to what students want } \\
\end{array}$ & Sweden \\
\hline 26. & Anbuthambi and Chandrasekaran & $\begin{array}{l}\text { motivate students } \\
\text { create interest in learning } \\
\text { students are encouraged to ask } \\
\text { time discipline }\end{array}$ & India \\
\hline 27. & Zamani and Ahangari (2016) & $\begin{array}{l}\text { good relationships with students } \\
\text { student self-confidence } \\
\text { the ability to maintain discipline in the classroom }\end{array}$ & Iran \\
\hline 28. & Kim, Jörg, and Klassen (2019) & $\begin{array}{l}\text { openness } \\
\text { awareness } \\
\text { extraversion } \\
\text { friendliness } \\
\text { emotional stability } \\
\text { teaching evaluation } \\
\text { learner achievement self-effectiveness } \\
\text { classroom views } \\
\text { educational attainment } \\
\text { tutor passionate steadiness } \\
\text { extraversio } \\
\text { precision }\end{array}$ & - \\
\hline 29. & Jan (2017) & mastery of content teaching skills as well & India \\
\hline
\end{tabular}




\begin{tabular}{|c|c|c|c|}
\hline No. & Writer(s) & Attributes identified & Country \\
\hline & & integrate teaching with technology & \\
\hline 30. & Coskun (2019) & $\begin{array}{l}\text { prepare each student in accordance with the hope that students will take inspiration } \\
\text { as a facilitator }\end{array}$ & $\begin{array}{l}\text { Literature } \\
\text { Review }\end{array}$ \\
\hline 31. & Alzeebaree and Hasan (2020) & $\begin{array}{l}\text { English language skills } \\
\text { read English well, } \\
\text { manage the classroom well } \\
\text { are confident and own } \\
\text { self-control }\end{array}$ & $\begin{array}{l}\text { Kurdistan } \\
\text { Irak }\end{array}$ \\
\hline 32. & McKay and Barton (2018) & $\begin{array}{l}\text { personal resources } \\
\text { strategic } \\
\text { contextual }\end{array}$ & Australia \\
\hline
\end{tabular}

Below, we present the expected competencies to master by teachers of Indonesia. There are four main competencies comprise pedagogical skill, personality skill, professional skill, and social competence. Each of the main competence has its indicators and subdescriptive indicators. We present the main and indicator in Table 2.

Table 2: The Expected Competencies Teachers of Indonesia

\begin{tabular}{|c|c|c|}
\hline & Competency & Indicators \\
\hline \multirow{10}{*}{1} & \multirow{10}{*}{$\begin{array}{l}\text { Pedagogic } \\
\text { Competence }\end{array}$} & Mastering learners from natural, ethical, human, cultural, passionate, and intelligent aspects. \\
\hline & & Comprehending education ideas and laws of instructional education. \\
\hline & & Cultivating a curriculum linked to the field of improvement being managed. \\
\hline & & Coordinating instructional advancement projects. \\
\hline & & $\begin{array}{l}\text { Employing delivery and transmission technology for the advantage of creating instructional development } \\
\text { activities. }\end{array}$ \\
\hline & & Promoting the growth of the potential of learners to achieve their diverse potentials. \\
\hline & & Interacting efficiently, emphatically, and politely with students. \\
\hline & & Executing an appraisal and evaluation of studying stages and results. \\
\hline & & Using the outcomes of the appraisal and evaluation for the profit of education. \\
\hline & & Reflecting to promote the quality of training. \\
\hline \multirow{6}{*}{2} & \multirow{6}{*}{$\begin{array}{l}\text { Personality } \\
\text { Competence }\end{array}$} & Performing in accordance with the moral, legal, common, and state cultural standards of Indonesia. \\
\hline & & Displaying oneself as a respectable, noble quality, and exemplary for learners and community. \\
\hline & & Displaying oneself as an individual who is steady, firm, knowledgeable, perceptive, and dependable. \\
\hline & & Describing a craft ethic, great trust, feeling of self-esteem in being an instructor, and self-confidence. \\
\hline & & Upholding the principles of standards of the teaching profession. \\
\hline & & Reflecting to enhance the state of education. \\
\hline \multirow{5}{*}{3} & \multirow{5}{*}{\begin{tabular}{|l} 
Social \\
Competence
\end{tabular}} & Acting in accordance with the moral, legal, common, and state educational standards of Indonesia. \\
\hline & & Displaying oneself as a correct, noble quality, and exemplary for learners and community. \\
\hline & & Displaying oneself as an individual who is firm, stable, knowledgeable, learned, and reliable. \\
\hline & & Displaying a craft ethic, great reliability, a feeling of dignity in being an instructor, and self-confidence. \\
\hline & & Bracing the principles of integrity of the education profession. \\
\hline \multirow{5}{*}{4} & \multirow{5}{*}{$\begin{array}{l}\text { Professional } \\
\text { Competence }\end{array}$} & Mastering substance, building, thoughts, and logical mindsets that underpin the topics being explained. \\
\hline & & $\begin{array}{l}\text { Taking control of competency criteria and fundamental competencies in the field of development is } \\
\text { managed. }\end{array}$ \\
\hline & & Promoting imaginative training substances. \\
\hline & & Advancing professionalism in a sustainable way by practicing contemplative performance. \\
\hline & & $\begin{array}{l}\text { Employing ICT (technology of information and communication) to deliver and develop teaching and } \\
\text { learning. }\end{array}$ \\
\hline
\end{tabular}

\section{Discussion}

\subsection{Question 1: what are the attributes of a good teacher?}

Our investigation of 32 documents from 21 countries revealed differences in the details of the characteristics of good teachers. Each document focuses on a particular feature of concern and is within the reach of the author. The details of the differences can be understood due to cultural and geographical differences. Even if we dig deeper, in each country the geographical and cultural location will be different (see Table 1). 
Cultural differences also determine the focus of attention of researchers. In countries with a culture of confusionism, it will be different from countries with an open, egalitarian, and democratic culture (Shi, 2006). In Hong Kong, a good teacher is one who supports student learning, encourages critical thinking, clear displays backed by appropriate, and effective models (Morrison \& Evans, 2018). While in Europe it is using many activities in couple practice and group work where students can interact and be active, participate in the learning process, have deep expertise, subject matter, deep interest, have passion, have the ability to use a variety of ways, method, strategy, flexible, describe the curriculum in a simple and natural way that students believe, personality teacher, knowledge of English, mastery, pedagogical skills, knowledge of planning methodologies (Tarajová \& Metruk, 2020).

5.2 Question 2: Do the characteristics of a good teacher of Indonesia match those found in various world studies?

Teachers have been legally acknowledged as a profession by the government of Indonesia since 2005 . This official recognition is in accordance with the 2005 Teacher and Lecturer Law (Republic of Indonesia, 2019). Moreover, a teacher must meet standards referring to Indonesian government regulations which consist of (a) Statute of the Minister of National Education Number 16 the Year 2007 pertaining to Academic Qualification and Teacher Capability, (b) National Education Standards Agency (BSNP) 2008 regarding Indicator Frameworks for Recording Achievement of National Education Standards: Academic Qualification Standards and Teacher Ability, (c) Permen PAN and RB Number 16 the Year 2009 concerning Teacher Functional Position and Credit Point. The Indonesian government's version of good teacher standards is in line with the characteristics of good teachers which have been proven through research. There are many traits of a good teacher, but they are part of four teacher competencies which cover pedagogical ability, professional ability, social ability, and personality ability (PermenPAN-RB).

\subsubsection{Pedagogical Competence}

This literature review centers on scientific documents describing the best possible teachers. After we check the documents to the past, we can find a list of features that focused on the role of the teacher and individuality traits that comment on the best possible teacher. Researchers continue to collect the features of a good teacher including personality. On the authority of comparative study in the Federal Republic of Germany, traits such as hopefulness, fair-mindedness, forbearance, self-trust, affection, and athletic look are considered the most important traits. While, Poles believe that professional understanding, a high level of morals, honorableness, self-trust, stability, justice, selfmanaged, and hopefulness make a teacher become a good teacher. Further, Hungary claims that professional understanding, common understanding, deep affection to pupils, morals sense, the feeling of occupation, meeting high quality, flawless behavior, feeling of pedagogy, hopefulness, suggestiveness are important qualities of a good teacher (Baller et al., 2003; Ida, 2017).

Tóth Albert collects personality traits that make successful teachers who take the role of leaders. Tóth Albert asked elementary school students aged six to seven to write an article entitled "My Role." As it turned out, only 13 of 127 kids stated that their exemplary person was their teacher. Those kids list the characteristics as follows: (a) deep affection to children (b) goodness (c) equitableness, (d) skilled in teaching and broad-scale expertise, (e) to be confident, challenging feeling, and stable, (f) to be friendly, (g) to be a nice looking, courteous. While, from the teacher's perspective, a good teacher is unprejudiced and truthful, deep affection for the job, stability, on time, and well managed are the most important traits for a good teacher (Ida, 2017; Tamás, 2001; Tóth, 1985).

As the results of the study made on educator and learners in 1998, it disclosed that a great teacher has characteristics such as affectionating but firm, requesting but understanding, consistent, 
unbiased, fair-minded, straightforward, patient, courteous, and cultured. The teacher should be a companion, a guide, and an expert in subject knowledge (Tamás, 2001).

A study conducted by Agnes identified two classifications of teachers in the period 1980s and 1990s. The two groups were explained based on the role of the teacher and their character traits. The traits included a senior teacher in the sense of expert in the field, had authority, position, and trust, unprejudiced, authoritative, and discipline. Another type was a teacher with a pedagogical visionary, nice temper, tolerant, and friendly. This research confirmed that the existence of two kinds of groups but several shifts were identified such as an improvement in professional knowledge and the parts of teachers as subject matter experts. Being a role of a good model for kids was still highly significant. However, the shifts in society brought about shifts in the role of teachers (Âgnes, 1997; Ida, 2017).

Emöke describes the various degrees of teacher tasks. The sociological degree is the institution, the group in which the educator tasks, and where the teacher contributed to the growth of the group. The degree of common mental was an introduction to the energetics of managers, classes, and groups. The third degree was the conservation and growth of educator-leaner relationships. As claimed by Bagdy, a globalized information society supplied designated teachers with a new kind of energy, dedicated to growth, innovation, and sympathetic, having managerial views, and competent in making an atmosphere of trust (Emőke, 1997; Ida, 2017). The outcomes of previous researches have the same purpose. They said that all teacher roles and characters shift depending on socio-economic shifts. Ottó claimed that the shifts of the teacher's role had grown in the present era. The teacher's role has a multi-construction: manager, information supplier, organizer, participator, advisor, friend, and support. The construction was changing very quickly (Katona, 2017).

As for the outcomes of the study of the global documents, a group of experts who concern the significance of character attributes. As they claimed, a general teacher is submissive, courteous, accountable, practical, down-to-earth, and empathic. The teacher is capable to do the task, obey all the rules that are obvious to him, such as stability, computability (Rippon \& Martin, 2006). Rushton, Morgan, and Richard studied America's pedagogical elite. They explained them as visionary, and supporters who are proud of their personality. They are active, eager, extroverted, cheerful, spontaneous, and adaptive (Rushton, Morgan, \& Richard, 2007).

Referring to the results of research in America conducted in the 1990s; teachers became the center of attention that teachers in Hungary played a role as good public resources and contributed to community development. Successful teachers, in their teaching practice, involve students through active activities through activities such as arguing, discussing, investigating, writing opinions, evaluating, experimenting, developing models, seeking information, providing information, and also direct practice. Teachers create a high and clear base, provide regular feedback on the progress of their students, good for learning environment, involve parents in their students' learning, and collaborate with various stakeholders. These teacher skills, if applied to prospective educators, make prospective educators active in carrying out their teaching careers and make these skills as normal activities and are considered routines, such as digging to get new strategies and techniques according to students' needs to change old ways that have been used ineffective. Prospective teachers and teachers must have the awareness of doing these tasks throughout their lives to keep learning (Darling-Hammond \& Baratz-Snowden, 2007; Haider \& Jalal, 2018; McGraw, Dresden, Gilbertson, \& Baker, 2017).

The results of studies from education experts in America who had tried to explore the factors that make a teacher good or bad, they found that general skills, intelligence, mastery of the material, qualifications, and tenure were not directly proportional to student achievement. That is why Americans are aware of the importance of openness and liability in all features of educational life. The effectiveness of the teacher's task is the main culmination so that it becomes a reference in the educational process. For this purpose, a new standard is needed to expand the old quality standard in teaching competence (Sagi \& Szemerszki, 2018) 


\subsubsection{Personality Competencies}

The personality traits are necessary to carry out association work favorably. His study confirmed distinctions between the representations accepted in the ended group and in the not-close group. If the representation includes a great number of students of various ages, the outcomes turn out to be surprising in combination: profound expert insight, profound concern in learners, a feeling of knowledge, and a feeling of entertainment are basic oneself traits of good educators. The outcomes differ in not-opened groups. Within society, learners' self-image takes advantage and has a profound influence on learners' relationships with others (Blanka, 1977). A triumphant instructor is considered humanly positive, steady, and knowledgeable, and flexible. She is able to establish a good model for teenagers and discovers a balance between her message and arousing learners in certain situations by restricting them. Further, she is able to provide energy to her learners to improve academic, ethical, aesthetic emotions, and common obligations by being resilient and agile (Blanka, 1977; Ida, 2017; Németh \& Garai, 2019).

Teacher skills are an explanation of the quality of teacher behavior that the teacher shows and is fully meaningful (Park, Jang, Thomas, \& Smith, 2020; Van der Zee \& Van der Gang, 2007). Other experts state that teacher competence is the ability of a teacher to be responsible for carrying out the main and additional tasks as well as possible (Ma'arif \& Rofiq, 2018). There are at least three competencies that teachers must master, namely the competence to realize the learning objectives made, personality competencies as a prerequisite for achieving educational goals, and behavioral competencies that explain behavior to achieve educational goals (Semin, 2019). Regarding the requirements for instructor competence in Indonesia, Law Number 14 of 2005 explains that skill is a collection of acquaintances, abilities, and practices that educators need to possess, feel, and master in order to carry out their professional duties. The instructor is tasked with mastering and applying it as a form of contribution in achieving educational success. The Indonesian government demands that because teachers have an important influence on the formation of students' personalities and become role models in passionate learning (Republic of Indonesia, 2019). Teachers who teach with enthusiasm, the spirit of the teacher will affect the behavior of students to be enthusiastic too (Isjoni, Daud, \& Azhar, 2019). The competence of the teacher's personality will affect the emotional condition of students to be carried over to the spirit of the teacher. The spirit of the teacher is reflected in the teacher carrying out the task of teaching and educating his students. The spirit of the teacher, unconsciously, affects the enthusiasm of students in learning through the stages of completing their learning tasks (Lumbantobing, 2020).

Agreeing with the importance and influence of teachers, Darajat strongly emphasizes that teachers have and uphold their personality as educators. Personality should be a prerequisite for prospective teachers because the true future is in the hands of the teacher. The world's future painter is a teacher through teaching practice to his students. The maturity of the teacher's personality also reduces the turmoil of the young souls of students who are in a period of searching for identity. Many students enjoy learning because of their teachers. Also, many students hate studying because of the teacher. The teacher's personality is very important for the future of the world (Irwansyah, Nasution, \& Afrida, 2019; Putra, 2018).

Teachers as role models must always train and practice discipline to students. The logic that is built is how the students will be disciplined if the teacher is not disciplined. In the learning process, the teacher must condition discipline. The teacher must model the discipline of learning and it must be the goal of the many learning objectives. Discipline is an important key part of achieving goals and discipline is an integral part of the central teacher's personality.

Discipline is a mental attitude and desire that is shown through a willingness to comply with the agreements that are institutionalized in the rules, values, and norms of life and are responsible for the tasks requested and assigned to them. The motivation to comply with the agreement that the teacher exemplifies radiates to students and students will be motivated to do the same. In short, the teacher who exudes the good behavior of students will imitate and students will also swallow the bad 
behavior of the teacher. Student behavior can be a feedback for the improvement of the teacher's personality both individually and collectively in an organization (Luneto, 2021; Oteng, 1983).

The results of research on personality competencies show that personality competencies greatly determine student behavior. Student behavior is directly proportional to the behavior expressed by the teacher. The personality competence referred to refers to a personality that is stable as measured by indicators of obedience to legal norms, social norms, likes to work as an educator, and has stability in acting; maturity is measured by indicators of independence in acting, has a work ethic, (Lin, Barros, \& Foulkes32) wisdom is measured by indicators of useful, open actions, authority is measured by indicators of positive attitudes and attitudes that bring respect, and (5) morals noble is assessed by indicators acting in in agreement with religious norms and behavior (PermenPAN-RB; Rinawati, 2019).

\subsubsection{Social Competence}

Social skills are important because humans are social creatures. He cannot live alone. Humans need other people to fulfill their needs. The social skills that people must master are not only local social skills but also global social skills. To be able to model social skills, teachers must be aware of their social skills, both local and global.

Social skills should be inculcated as soon as possible in childhood. Some aspects of social skills such as cooperation, self-management, assertiveness will be carried over to the ability to adapt in the future (Gresham \& Elliott, 1987). Inculcating social skills as soon as possible can help students become skilled at interacting with peers in a positive way. The social skills that students get will help students learn behavior through imitating their friends as well. Peers are also a source for various behaviors such as support and acceptance (Walker \& Barry, 2018). Conversely, children who do not succeed in mastering social skills will not be able to develop social skills at an early stage of development dan often displaying social problem behaviors (Little, Swangler, \& Akin-Little, 2017). Children who have a deficit in their social skills will experience barriers to their emotional development. He tends to have difficulty communicating with his peers, teachers, and family (Soares et al., 2019). In addition, being unskilled in social use is shown by a negative relationship with behavioral adjustment skills (Hygen et al., 2020). Students who display unskilled social behavior will get worse if the adults around them are not responsive to change them. As a consequence, children's weaknesses in social skills will be carried over into adulthood. It will be worse if they perceive others as discriminatory against him.

Educators must understand that the deficit in adjustment behavior stems from two major dimensions of symptoms. The symptoms are the externalization and internalization of behavior (Machado et al., 2019). Internalization of behavior is indicated by the behavior of worry, anxiety, depression, and somatic complaints. On the other hand, behavioral externalization is indicated by hyperactivity, inattention, aggression towards friends, and self-management problems (Oh, Greenberg, \& Willoughby, 2020). The internalization and externalization of behavior strongly influence each other over time. Internalizing behavior predicts externalizing behavior in the future, and vice versa (Arslan, 2020).

As it is said that social skills predict internalizing and externalizing behavior during childhood, they are carried over to the next period: adolescence and adulthood, and can last much longer. In addition, poorer competence predicts higher levels of internalization and externalization barriers (Gardiner \& Iarocci, 2018). Children who have few social skills have difficulty expressing them and understanding others. The obstacles are in the form of sending wrong messages, wrong responses to friends and teachers, including misunderstandings with family. As a result, children with social difficulties have few positive interactions, and find themselves in difficulty interacting with others. Thus, individuals like this are rejected and considered socially incompetent by many people (Splett et al., 2019). Therefore, children with less social skills are at high risk of experiencing social exclusion so that these children feel the world is not friendly to them and experience feelings of anxiety and 
rejection from their friends.

In line with the description above, to be able to teach professionally in their field, in addition to having pedagogic skills, personality skills, teachers must master social skills. Social skills are demanded by students to achieve in building relationships with others, including human interplay skills and human obligation (Hamidi \& Indrastuti, 2012; Surya, Syahputra, \& Juniati, 2018). Therefore, the Indonesian government issued Ministerial Rule No. 19 of 2005 which states that social skills contain the ability to make contact with, socialize in schools and communities. Social skill is the capacity of educators as part of the population to make contact with and interchange successfully with other people who contain: students, accompanying teachers, parents, and the community. The measures applied in measuring teacher social skills contain the ability to make contact with and interchange successfully with learners, peer teachers, and personnel, mothers and fathers, learners, and the society (Mulyasa, 2007).

\subsubsection{Professional Competence}

Teacher competencies related to teaching skills are called professional competencies. Professional competence is the skill in transferring the content of the material listed in the curriculum. Mastery of the material must be comprehensive covering the substance of the material, the field of science and philosophy (El-Jardali, Tchaghchagian, \& Jamal, 2009).

One of the professional competencies is mastering curriculum documents. The Curriculum Document contains Competency Standards (SK) and Basic Competencies (KD). Teachers who master $\mathrm{KD}$ mean that the teacher is able to translate it into a series of educational learning. Teachers armed with $\mathrm{KD}$ are able to translate them into indicators of learning achievement, formulate goals, determine the right time allocation, determine sources, materials, and tools, compile assessment instruments from grids, question cards, and questions that are ready to be used to measure success, analyze the outcomes of the appraisal, and ultimately decide the level of success of education. Furthermore, based on the evaluation to determine the follow-up, it could be in the sort of correction and/or enrichment education. The outcomes of the study from the application of learning, the teacher can evaluate what causes the success and failure of learning. Armed with the results of the analysis, the teacher can conduct research and critical analysis of learning aspects (Höner, Leyhr, \& Kelava, 2017; Ma, Xin, \& Du, 2018; Williams \& Saunders, 2020).

Referring to the explanation, the Indonesian government developed a regulation that a teacher can be called a professional teacher. He must meet four criteria which include four competencies. The four competencies are pedagogic, personality, professional, and social competencies. The four main competencies are developed into indicators and sub-indicators. Thus, it is clear to us that there is a match between the competence of Indonesian teachers and the competence of world teachers.

\subsection{Question 2, what are the gaps in the characteristics of good teachers in Indonesia to become} psychologically prosperous teachers?

There are still complaints from the stakeholders that certified teachers in Indonesia have a gap between expectations and reality. The hope is that teachers who have been certified will have optimal performance. Stakeholders' expectations of optimal teacher performance because teachers who have been certified get a salary double the salary received before being certified. Stakeholder complaints arise from the frequent publication of global assessment reports where meetings in Indonesia have not improved. Based on tracing world research, a gap was found in the form of awareness. The gap is in the form of teachers who are aware of their choices as teachers. Indonesia teachers must dare to admit that being a teacher is not entirely the first choice of their profession and not because of awareness. The teaching profession was chosen as the second, third, or because of their inability to achieve their main professional dreams.

Peaceful thoughts are the source of happy feelings. Happy individuals perform better than those 
who live in anxiety. Getting a peaceful mind can be practiced through mindfulness training to get mindfulness. Starting from practice in the medical field, awareness training is practiced in other disciplines including education. The rapidity of mindfulness training is driven by the empirical fact that many people regain their health from illnesses such as cancer, chronic pain, anxiety disorders, and depression from mindfulness training (Baer, 2007). The available data shows a real success rate, the more adults are interested in getting involved in the training. Perceived impacts include improved health and well-being, improved neuroendocrine and invulnerable system purpose; improve conformity to medical care, encouragement to make the way of life shifts; foster social relationships and enrich interpersonal relationships as well as reduce stress and anxiety, drug dependence, and change the perception of pain perception (Basler et al., 2020; Langer \& Ngnoumen, 2018).

Awareness is described as the awareness that arises through focusing on a goal to the exclusion of the occurrence of self-blame experiences from time to time. Goal-focusing and setting aside feelings of guilt are basic elements of awareness and human mental faculties that can be strengthened. Mindfulness meditation for mindfulness is one of those methods. While mindfulness meditation has its origins in Buddhist practice, Western mindfulness experts have adapted from traditional practices to modern practices. This adjustment brings medical and psychological benefits (Crane et al., 2017; Kabat-Zinn, 2017).

The application of contemplation begins with the practice of focusing on single mindfulness followed by the practice of breathing, sensing, and loving-kindness. The goal of this practice is to develop a gradually clearer awareness through the practice of increasing admission. Paying attention to whatever appears to be reacted by increasing the quality of admission and non-evaluation heads to improve clearness and steadiness of concern. This practice results in diminished reactions in the body's physiological stress response (Carmody \& Baer, 2008).

Teachers struggle with various stressors in carrying out their routine tasks. However, teachers are armed with very limited resources to cope. Teacher stress is demonstrated by a survey that shows that teachers experience moderate to high levels of stress and many documents document the causes and effects of stress in teaching (Montgomery \& Rupp, 2005). In amazement, empirical research that suggests solving problems related to teacher job stress and burnout is rarely carried out (Majnemer et al., 2008). There is a list of demands for a teacher's job. Teachers are required to be able to provide an educational learning environment within the framework of delivering subject matter. Teachers must be responsive to students, parents, co-workers, train students in conflict and seek solutions through the preparation of learning scenarios, exemplify superior emotional management, model the handling of bullies, and present themselves as role models (Jennings \& Greenberg, 2009).

The condition of Indonesian teachers needs to get more diverse treatment if they don't want to suffer more. It is because teachers have to respond to a number of demands from the government and the world. It is true that teachers receive training but the training conveys more of the material demanded by the teacher and has not provided assistance to the teacher's difficulties. Teachers should also pursue the educational achievements of more fortunate countries. Indonesian teachers are said to be disadvantaged because the Indonesian government manages teachers in a range and with various conditions and with varying social degrees. This condition must be known by the world because this will be the responsibility of the world that is increasingly burdensome.

For Indonesian teachers, it is clear that the need for innovative and cost-effective methods for schooling supports the resilience and ability of teachers to remain in their chosen profession. Neuroscience offers about the whys and hows of mindfulness training. Almost all teachers open a side job by opening an online shop. This activity seems to be an alternative entertainment for teachers. Neuroscience expands on the resilience of the mind, and the ability of the mind to generate new neurons and links between nerves over time. This practice promotes multiplier improvement as is done in both cognitive and affective neuroscience research. This kind of research is motivated by neuroscience studies relating to the effect of mindfulness coaching on higher mind activity and cortical function (Sandrone \& Schneider, 2020). 
The term mindfulness practice is also known as reflective practice. Decades of neuroscience, medical, and adult psychology research have shown accumulating evidence that teachers too may be useful individually and professionally from intellective practice. This discipline rests on mindfulness and awareness. This practice studies a broad field and involves assessable physiological and psychological advantages through the degradation of physiological stress levels in the usage and composition of various brain regions. Areas of the mind affected by mindfulness coaching are also involved in executive function (EF) and the control of emotion and expression. EF is a general name for cognitive methods. Cognitive functions include preparation, thought, attention, problem-solving, oral argumentation, interference, thoughtful elasticity, multi-tasking, initiation, and control of actions (Chan, 2008). In short, data-based research shows that mindfulness training promotes increased endurance and more optimal brain use in adults, including in the field of teaching (Howard-Jones, 2010).

A study using a randomized controlled test (RCT) in a group of healthy working people showed that over eight weeks of training there was a reduction in stress levels based on mindfulness (MBSR). This practice also reduces subjective feelings of stress, increases subjective feelings of well-being, and improves bodily functions, decreasing brain work in areas of the brain related to bad emotions and conversely increasing activity in areas related to good emotions (Davidson et al., 2003).

The results of the study revealed that increasing and developing attention through attention training can reduce emotional stress and create a more positive state of mind and the subsequent impact is a higher quality of life. Training also affects the brain's autonomic neurological system, pressure hormones, the protected method, and healthy living ways, such as consuming, resting, and using certain substances in beneficial habits (Greeson, 2009; López Valmaña, 2019). More time for mindfulness improves mood swings and stress symptoms (Bishop et al., 2004; Brown, Ryan, \& Creswell, 2007).

Meditation can mean surrendering through religious rituals that the teacher adheres to. This relates to the typical Indonesian people who believe in God. Understanding the reason for the creation of humans which includes where, for what, and where to go afterlife in the world is a true form of mindfulness-awareness. The aftermath of this is that the teacher is at peace and at peace of mind as well. Thus, Indonesian teachers are fully aware of the role and importance of a profession that carries out a perfect humanitarian mission to sustainably manage a better world and be able to coexist with all the differences and dynamics of the students' future lives.

\section{Conclusion}

After going through an in-depth investigation of the characteristics of a good teacher from various studies that have been published in various journals, the authors conclude that 1 ) the characteristics of a good teacher are in accordance with the prerequisites for becoming a professional teacher in the Indonesian version, 2) there is a gap in the characteristics of a good teacher. a good teacher between the Indonesian version of a good teacher and research that has been published in journals, namely mindfulness awareness.

\section{Suggestion}

Referred to an analysis in-depth, the authors suggest that education stakeholders in Indonesia include a supporting element, namely mindfulness awareness. Mindfulness awareness can be run based on the religious beliefs of each teacher. This is because Indonesians are religious people who always maintain a harmonious relationship between themselves, other people including nature, and God.

\section{Disclosure Statement}

This research is funded by Universitas Lampung. This research does not have a conflict of interest with any institution. 


\section{References}

Ágnes, B. (1997). A gyermekkor változó színterei. Németh András: Nevelés.

Akhtar, H. (2017). Psychological Well-Being of Volounteer Teacher Trainers in The Remote Area in Indonesia. International E-Journal of Advances in Social Sciences, 3(9), 840-849.

Akyeampong, K. (2017). Teacher educators' practice and vision of good teaching in teacher education reform context in Ghana. Educational researcher, 46(4), 194-203.

Alzeebaree, Y., \& Hasan, I. A. (2020). What makes an effective EFL teacher: High School Students' Perceptions. Asian ESP Journal, 16(2), 169-183.

Anbuthambi, B., \& Chandrasekaran, N. Key Attributes of A Good Teacher in An Engineering College.

Arslan, G. (2020). Measuring emotional problems in Turkish adolescents: Development and initial validation of the Youth Internalizing Behavior Screener. International Journal of School \& Educational Psychology, 1-10.

Aydin, H., Ogurlu, U., Andrew, K., Masalimova, A. R., Dorozhkin, E. M., \& Malygin, A. A. (2019). High school students' perceptions of global citizenship in central public high schools: Implications for teacher educators. Revista de Cercetare si Interventie Sociala, 65, 187-205.

Baer, R. A. (2007). Mindfulness, assessment, and transdiagnostic processes. Psychological Inquiry, 18(4), 238-242.

Baier, F., Decker, A. T., Voss, T., Kleickmann, T., Klusmann, U., \& Kunter, M. (2019). What makes a good teacher? The relative importance of mathematics teachers' cognitive ability, personality, knowledge, beliefs, and motivation for instructional quality. British Journal of Educational Psychology, 89(4), 767-786.

Baller, E., Golnhofer, E., Falus, I., Kotschy, B., Nadasi, M., Nahalka, I., . . . Vamos, Á. (2003). Didaktika-Elméleti alapok a tanítás tanulásához.

Basler, J., Lancaster, R. J., Schmitt, C. A., Hong, P. Y., Malcore, M., Docter, A., \& Wallace-Leece, J. (2020). Mindfulness and Patient Safety Simulation in Third-Year Baccalaureate Students. Clinical Simulation in Nursing, 42, 8-11.

Benekos, P. J. (2016). How to be a good teacher: Passion, person, and pedagogy. Journal of Criminal Justice Education, 27(2), 225-237.

Bishop, S. R., Lau, M., Shapiro, S., Carlson, L., Anderson, N. D., Carmody, J., . . Velting, D. (2004). Mindfulness: A proposed operational definition. Clinical psychology: Science and practice, 11(3), 230-241.

Blanka, G. D. (1977). A tanár-diák kapcsolatról: Tankvk.

Braun, S. S., Roeser, R. W., Mashburn, A. J., \& Skinner, E. (2019). Middle school teachers' mindfulness, occupational health and well-being, and the quality of teacher-student interactions. Mindfulness, $10(2)$, 245255.

Brown, K. W., Ryan, R. M., \& Creswell, J. D. (2007). Addressing fundamental questions about mindfulness. Psychological Inquiry, 18(4), 272-281.

Cansoy, R., \& Parlar, H. (2018). Examining the relationships between the level of schools for being professional learning communities and teacher professionalism. MOJES: Malaysian Online Journal of Educational Sciences, 5(3), 13-27.

Carmody, J., \& Baer, R. A. (2008). Relationships between mindfulness practice and levels of mindfulness, medical and psychological symptoms and well-being in a mindfulness-based stress reduction program. Journal of behavioral medicine, 31(1), 23-33.

Celik, B. (2017). Teaching profession and passion. International Journal of Social Sciences E Educational Studies, 4(2), 85-92.

Chan, Y. E. (2008). Why haven't we mastered alignment? The importance of the informal organization structure. MIS Quarterly executive, 1(2), 2.

Cook-Sather, A., \& Baker-Doyle, K. (2017). Developing teachers' capacity for moral reasoning and imagination in teacher education. The Sage handbook of research on teacher education, 354-368.

Coskun, L. (2019). What Kind of Teacher Opens Facilitating Ways for Purposeful Learning?

Crane, R., Brewer, J., Feldman, C., Kabat-Zinn, J., Santorelli, S., Williams, J., \& Kuyken, W. (2017). What defines mindfulness-based programs? The warp and the weft. Psychological medicine, 47(6), 990-999.

Darling-Hammond, L., \& Baratz-Snowden, J. (2007). A good teacher in every classroom: Preparing the highly qualified teachers our children deserve. Educational Horizons, 85(2), 111-132.

Davidson, R. J., Kabat-Zinn, J., Schumacher, J., Rosenkranz, M., Muller, D., Santorelli, S. F., . . Sheridan, J. F. (2003). Alterations in brain and immune function produced by mindfulness meditation. Psychosomatic medicine, 65(4), 564-570.

De Winter, J., \& Airey, J. (2019). What makes a good physics teacher? Views from the English stakeholder community. Physics Education, 55(1), 015017. 
Dogan, B., Yildirim, K., Cermik, H., \& Ates, S. (2020). Promoting Pre-Service Teachers' Reading Attitudes through Literature Circles: A Mixed Methods Design. International Journal of Educational Methodology, 6(4), 653-667.

El-Jardali, F., Tchaghchagian, V., \& Jamal, D. (2009). Assessment of human resources management practices in Lebanese hospitals. Human resources for Health, 7(1), 1-9.

Emőke, B. (1997). A pedagógus hivatásszemélyisége. KLTE Pszichológiai Intézet, Debrecen.

Esteban Bara, F., \& Mellén Vinagre, T. (2019). Becoming a teacher: the thoughts of undergraduates training to work in Primary Education and ideas for their university education. Educational Studies, 45(5), $633-645$.

Fleer, M. (2018). The Role of Subjectivity in Understanding Teacher Development. Subjectivity within CulturalHistorical Approach: Theory, Methodology and Research, 5, 149.

Gardiner, E., \& Iarocci, G. (2018). Everyday executive function predicts adaptive and internalizing behavior among children with and without autism spectrum disorder. Autism Research, 11(2), 284-295.

Ghenaati, A., \& Nastiezaie, N. (2019). Investigating the Relationship between Characteristics of a Good Teacher and Academic Engagement with Mediation of Academic Buoyancy of Graduate Students. Journal of Medical Education Development, 12(33), 34-42.

Grant, K. C. (2017). From teaching to being: The qualities of a mindful teacher. Childhood Education, 93(2), 147-152.

Greeson, J. M. (2009). Mindfulness research update: 2008. Complementary health practice review, 14(1), 10-18.

Gresham, F. M., \& Elliott, S. N. (1987). The relationship between adaptive behavior and social skills: Issues in definition and assessment. The Journal of special education, 21(1), 167-181.

Haider, A., \& Jalal, S. (2018). Good teacher and teaching through the lens of students. International Journal of Research, 5(7), 1395-1409.

Hamidi, M., \& Indrastuti, S. (2012). Influence Analysis of Competence, Educational Background on Performance Polikteknik Bengkalis Lecturer of Leadership Perspective. Paper presented at the Proceedings of the National Seminar on Industry and Technology.

Hargreaves, A. (1998). The emotional practice of teaching. Teaching and teacher education.

Höner, O., Leyhr, D., \& Kelava, A. (2017). The influence of speed abilities and technical skills in early adolescence on adult success in soccer: A long-term prospective analysis using ANOVA and SEM approaches. PloS one, $12(8)$, eo182211.

Howard-Jones, P. (2010). Introducing neuroeducational research: Neuroscience, education and the brain from contexts to practice: Taylor \& Francis.

Hygen, B. W., Belsky, J., Stenseng, F., Skalicka, V., Kvande, M. N., Zahl-Thanem, T., \& Wichstrøm, L. (2020). Time spent gaming and social competence in children: Reciprocal effects across childhood. Child development, $91(3), 861-875$.

Ida, Z. n. (2017). What Makes a Good Teacher? Universal Journal of Educational Research, 5(1), 141-147.

Irwansyah, M., Nasution, M. D., \& Afrida, A. (2019). Urgensi Kompetensi Kepribadian Guru dalam Sistem Pendidikan Perspektif Hadits Nabawi. Tarbiyah Islamiyah: Jurnal Ilmiah Pendidikan Agama Islam, 9(2).

Isjoni, I., Daud, A., \& Azhar, A. (2019). Integrity and Performance of High School Teachers in Pekanbaru. Indonesian Journal of Economics, Social, and Humanities, 1(1), 51-57.

Jabborov, U. (2020). Modeling the Pedagogical Experience of England as a Factor of Improving the Quality of Training Future Teachers. Архив Научных Публикаций JSPI.

Jamei, S. (2016). Students' and teachers' perceptions of a good teacher of ESL in three different secondary schools in Malmö. In: Malmö högskola/Lärande och samhälle.

Jan, H. (2017). Teacher of 21st century: Characteristics and development. Research on Humanities and Social sciences, 7(9), 50-54.

Jennings, P. A., \& Greenberg, M. T. (2009). The prosocial classroom: Teacher social and emotional competence in relation to student and classroom outcomes. Review of educational research, 79(1), 491-525.

Johnson, B. M., Miltenberger, R. G., Egemo-Helm, K., Jostad, C. M., Flessner, C., \& Gatheridge, B. (2005). Evaluation of behavioral skills training for teaching abduction-prevention skills to young children. Journal of Applied Behavior Analysis, 38(1), 67-78.

Johnson, D. W., \& Johnson, R. T. (2017). The use of cooperative procedures in teacher education and professional development. Journal of education for teaching, 43(3), 284-295.

Kabat-Zinn, J. (2017). Too early to tell: the potential impact and challenges-ethical and otherwise-inherent in the mainstreaming of dharma in an increasingly dystopian world. Mindfulness, 8(5), 1125-1135.

Kadioglu Ates, H., \& Kadioglu, S. (2018). Identifying the Qualities of an Ideal Teacher in Line with the Opinions of Teacher Candidates. European Journal of Educational Research, 7(1), 103-111.

Katona, G. (2017). A kisgyermeknevelés jelentősége és társadalmi hatása.

Kim, L. E., Jörg, V., \& Klassen, R. M. (2019). A meta-analysis of the effects of teacher personality on teacher effectiveness and burnout. In: Springer. 
Langer, E. J., \& Ngnoumen, C. T. (2018). Mindfulness.

Lin, D., Barros, C., \& Foulkes32, C. (2014). Beyond Insular Education Policy: Learning to live together in the face of climate change in the Pacific. The of Education.

Little, S. G., Swangler, J., \& Akin-Little, A. (2017). Defining social skills. In Handbook of social behavior and skills in children (pp. 9-17): Springer.

López Valmaña, E. (2019). Mindfulness-based intervention for chronicpain in children and adolescents: systematic review.

Lumbantobing, P. A. (2020). The Contribution of Lecturer Pedagogical Competence, Intellectual Intelligence and Self-Efficacy of Student Learning Motivation. Budapest International Research and Critics in Linguistics and Education (BirLE) Journal, 3(1), 564-573.

Luneto, B. (2021). Efektivitas Manajemen Kepemimpinan Kepala Madrasah di MAN 1 Kabupaten Gorontalo. Tadbir: Jurnal Manajemen Pendidikan Islam, 9(1), 76-91.

Lyngstad, I., Bjerke, Ø., \& Lagestad, P. (2019). 'The teacher sees my absence, not my participation'. Pupils' experiences of being seen by their teacher in physical education class. Sport, Education and Society, 24(2), 147-157.

Ma'arif, M. A., \& Rofiq, M. H. (2018). The model of character teacher: Phenomenology at Daruttaqwa Gresik Islamic Boarding School. ATTARBIYAH: Journal of Islamic Culture and Education, 3(2), 131-152.

Ma, N., Xin, S., \& Du, J.-Y. (2018). A peer coaching-based professional development approach to improving the learning participation and learning design skills of in-service teachers. Journal of Educational Technology $\mathcal{E}$ Society, 21(2), 291-304.

Machado, J. C., Barreira, D., Teoldo, I., Travassos, B., Júnior, J. B., Santos, J. O. L. D., \& Scaglia, A. J. (2019). How does the adjustment of training task difficulty level influence tactical behavior in soccer? Research quarterly for exercise and sport, 9o(3), 403-416.

Maddamsetti, J., Flennaugh, T. K., \& Rosaen, C. L. (2018). Who should teach? A Chinese teacher candidate's understandings of a good teacher and racialised experiences. Asia-Pacific Journal of Teacher Education, 46(2), 148-166.

Majnemer, A., Shevell, M., Law, M., Birnbaum, R., Chilingaryan, G., Rosenbaum, P., \& Poulin, C. (2008). Participation and enjoyment of leisure activities in school-aged children with cerebral palsy. Developmental Medicine E Child Neurology, 5o(10), 751-758.

McGraw, A., Dresden, J., Gilbertson, E., \& Baker, M. (2017). Site-based teacher education as a context for attending to the complexity and person-centred nature of teaching and learning: A narrative inquiry involving teacher educators from Australia and the United States. In Teacher Education Policy and Practice (pp. 51-65): Springer.

McKay, L., \& Barton, G. (2018). Exploring how arts-based reflection can support teachers' resilience and wellbeing. Teaching and teacher education, 75, 356-365.

Montgomery, C., \& Rupp, A. A. (2005). A meta-analysis for exploring the diverse causes and effects of stress in teachers. Canadian Journal of Education/Revue canadienne de l'éducation, 458-486.

Morrison, B., \& Evans, S. (2018). University students' conceptions of the good teacher: a Hong Kong perspective. Journal of Further and Higher Education, 42(3), 352-365.

Mulyasa, E. (2007). Menjadi Kepala Sekolah Profesional. Bandung: Remaja Rosdakarya.

Navickiené, V., Sedereviciuté-Paciauskiené, Z., Valantinaité, I., \& Zilinskaité-Vytiené, V. (2019). The Relationship between Communication and Education through the Creative Personality of the Teacher. Creativity Studies, 2019, 12 (1): 49-6o. Eng.) DOI: https://doi. org/10.3846/cs.

Németh, A., \& Garai, I. (2019). 2.1. 4 disciplinary Changes in the Hungarian Pädagogik from the second half of the 19th century to the collapse of Stalinist-type dictatorship. Blanka Kudláčová Andrej Rajský (Eds.), 210.

Nguyen, B. H., Haworth, P., \& Hansen, S. (2019). Challenging ESP teacher beliefs about active learning in a Vietnamese university. Teacher Development, 23(3), 345-365.

O'Donoghue, T. (2016). Being able to see the wood from the trees in courses of teacher education. Encounters in Theory and History of Education, 17, 165-176.

Oh, Y., Greenberg, M. T., \& Willoughby, M. T. (2020). Examining longitudinal associations between externalizing and internalizing behavior problems at within-and between-child levels. Journal of abnormal child psychology, 1-14.

Oteng, S. (1983). Administrasi pendidikan. Bandung: Bumi Aksara.

Park, N. K., Jang, W., Thomas, E. L., \& Smith, J. (2020). How to Organize Creative and Innovative Teams: Creative Self-Efficacy and Innovative Team Performance. Creativity Research Journal, 1-12.

PermenPAN-RB, 2009. Tentang jabatan fungsional guru dan angka angka kredit [on teacher's functional position and its credit score], 16 C.F.R. 
Platsidou, M., \& Diamantopoulou, G. (2020). Different Voices on Emotional Intelligence Skills of the Good Teacher: Teachers, Students and Parents. Journal of Education and Human Development, 9(2), 54-62.

Putra, R. F. L. (2018). Konsep Kepribadian Guru Menurut Zakiah Daradjat. IAIN Ponorogo,

Undang-Undang RI No. 14 Tahun 2005 tentang Guru dan Dosen, (2019).

Rinawati, A. (2019). The integration of prophetic values in developing the teachers' personality competency assessment instrument. Paper presented at the International Conference on Social Science and Character Educations (ICoSSCE 2018) and International Conference on Social Studies, Moral, and Character Education (ICSMC 2018).

Rippon, J. H., \& Martin, M. (2006). What makes a good induction supporter? Teaching and teacher education, 22(1), 84-99.

Roeser, R. W., Skinner, E., Beers, J., \& Jennings, P. A. (2012). Mindfulness training and teachers' professional development: An emerging area of research and practice. Child development perspectives, 6(2), 167-173.

Rushton, S., Morgan, J., \& Richard, M. (2007). Teacher's Myers-Briggs personality profiles: Identifying effective teacher personality traits. Teaching and teacher education, 23(4), 432-441.

Rusznyak, L. (2018). What messages about teacher professionalism are transmitted through South African preservice teacher education programmes? South African Journal of Education, 38(3).

Sagi, M., \& Szemerszki, M. (2018). Reforms in Teaching Professions and Changes in Recruitment of Initial Teacher Education in Hungary. Paper presented at the 3rd Central European Higher Education Cooperation (CEHEC) Conference Proceedings.

Sandrone, S., \& Schneider, L. D. (2020). Active and distance learning in neuroscience education. Neuron, 106(6), $895-898$.

Semin, F. K. (2019). Competencies of Principals in Ensuring Sustainable Education: Teachers' Views. International Journal of Evaluation and Research in Education, 8(2), 201-212.

Shi, L. (2006). The successors to Confucianism or a new generation? A questionnaire study on Chinese students' culture of learning English. Language, culture and curriculum, 19(1), 122-147.

Smith, E., \& Yasukawa, K. (2017). What makes a good VET teacher? Views of Australian VET teachers and students. International Journal of Training Research, 15(1), 23-40.

Soares, J., Barbosa-Ducharne, M., Palacios, J., Moreira, M., Fonseca, S., \& Cruz, O. (2019). Adopted Children's social competence: The interplay between past and present influences. Family Relations, 68(5), 565-579.

Splett, J. W., Garzona, M., Gibson, N., Wojtalewicz, D., Raborn, A., \& Reinke, W. M. (2019). Teacher recognition, concern, and referral of children's internalizing and externalizing behavior problems. School mental health, $11(2), 228-239$.

Surya, E., Syahputra, E., \& Juniati, N. (2018). Effect of problem based learning toward mathematical communication ability and self-regulated learning. Journal of Education and Practice, 9(6), 14-23.

Tamás, S. P. (2001). A szabadság idegtudománya. A Doktoranduszok Országos Szövetsége Filozófiatudományi Osztálya konferenciájának kötete, 117 .

Tarajová, R., \& Metruk, R. (2020). Characteristics of an effective EFL teacher: Perspectives of Slovak EFL students and teachers. European Journal of Education Studies, 7(12).

Teng, M. F. (2017). Emotional Development and Construction of Teacher Identity: Narrative Interactions about the Pre-Service Teachers' Practicum Experiences. Australian Journal of Teacher Education, 42(11), 117-134.

Tóth, A. (1985). A pedagógiai vezetés stílusa. Pszichológia a gyakorlatban. Akadémiai Kiadó, Budapest, 45, 35-37.

Van der Zee, K., \& Van der Gang, I. (2007). Personality, threat and affective responses to cultural diversity. European Journal of Personality: Published for the European Association of Personality Psychology, 21(4), 453470.

Walker, J. D., \& Barry, C. (2018). Assessing and supporting social-skill needs for students with high-incidence disabilities. TEACHING Exceptional Children, 51(1), 18-30.

Williams, R. D., \& Saunders, L. (2020). What the field needs: Core knowledge, skills, and abilities for public librarianship. The Library Quarterly, 9o(3), 283-297.

Zamani, R., \& Ahangari, S. (2016). Characteristics of an effective English language teacher (EELT) as perceived by learners of English. International Journal of Foreign Language Teaching and Research, 4(14), 69-88. 